Pak. j. sci. ind. res. Ser. B: biol. sci. 2019 62B(3) 206-218

\title{
Review
}

\section{A Review of Mycotoxin Types, Occurrence, Toxicity, Detection Methods and Control}

\author{
Naseem Zahra ${ }^{a b *}$, Nadia Jamila, Sajid Rashid Ahmad ${ }^{a}$, Muhammad Khalid Saeed ${ }^{b}$, \\ Imran Kalim ${ }^{\mathrm{b}}$ and Asma Sheikh \\ ${ }^{a}$ College of Earth and Environmental Sciences, University of the Punjab, Lahore, Pakistan \\ ${ }^{\mathrm{a}}$ Food and Biotechnology Research Centre, PCSIR Laboratories Complex, \\ Ferozepur Road, Lahore-54600, Pakistan
}

(received May 1, 2018; revised December 21, 2018; accepted April 17, 2019)

\begin{abstract}
Mycotoxins are health hazardous natural toxin produced by various fungal species due to favourable environmental conditions for fungal growth. These are carcinogenic, hepatotoxic and immunosuppressive substances usually found in food and feed items. Mycotoxins are broadly divided into two major groups on the basis of mycotoxin producing fungi i.e., those fungi which invade in pre-harvest conditions and those which are produced in post-harvest conditions called storage fungi. The conditions which promote mycotoxin growth are high temperatures, moisture levels, poor hygienic conditions and contamination during storage and transportation. Aflatoxins, ochratoxins, citrinin, trichothecene, fumonisins, patulin and zearalenone are prominent mycotoxins in food and feed commodities. This review renders the comprehensive data regarding occurrence of main mycotoxins, their analysis and health hazardous effects on human health alongwith some detoxification protocols.
\end{abstract}

Keywords: mycotoxin, detoxification, health hazard, metabolites

\section{Introduction}

Mycotoxins, the secondary metabolites formed by various Aspergillus fungal species Penecillium, Fusarium and Trichoderma are health hazardous poisons frequently present in food and feed (Tola and Kebede, 2016). These may be present as toxic compounds in feed and food like cereals, legumes, oilseeds and milk, vegetables, fruits having high levels of moisture and nutrients (Gizachew et al., 2016; Marin et al., 2013). Mycotoxins are one of the main public health concerns due to severe toxicity. All over the world work has been conducted on mycotoxins to evaluate its presence in different food entities and its severity (Berthiller et al., 2018; Yu et al., 2004). Toxic effects of mycotoxins on mammalian cell (Zain, 2011; Creppy, 2002) are given in Table 1.

Mycotoxins persuade and endanger economy, international trade as well as develop the irreversible health effects in living beings (WHO, 2006). Biosynthesis of mycotoxins defined that these are secondary metabolites concerned with internal factors like genetic potential of fungi and substrate and external factors like moisture

*Author for correspondence;

E-mail: naseem.zahra1981@gmail.com and temperature conditions in which crop is grown, harvested and stored (James, 2005).

Mycotoxin contamination is inevitable and at times capricious, which makes it an inimitable dispute to food safety. The favourable conditions for mycotoxins growth are started with poor hygienic circumstances at the time of haulage and storage, moisture, heavy rains and high temperatures (FAO, 1995).

Generally, mycotoxins cause severe circumstances by intake of unhygienic foods, inhalation of spore-borne toxins and by dermal contact with mold infected substrates. Effects by mycotoxins are carcinogenic, cytotoxic, teratogenic, estrogenic, immunosuppressant and neurotoxic (Benkerroum, 2016). This review paper briefly entails mycotoxins information including their structures, major types of mycotoxins, health hazardous effects, their analysis and different ways to control mycotoxin contamination. Most of the diseases related to mycotoxins are because of accumulating contaminated food (Alrabadi et al., 2018).

Chemical structure of mycotoxins. Mycotoxins are poisonous compounds having low molecular weight formed by fungal species which contaminate food and 
feed. These are diminutive and quite stable molecules which are very complicated to get rid of or eliminate (Milani, 2013; Steyn, 1995). Mycotoxins constitute chemically heterogeneous and toxigenically assembly that are grouped together. Several mycotoxins exhibit overlapping toxicities to humans, animals and plants (Bennett, 1987). The structures of major mycotoxins are given in Fig. 1.

Various types of mycotoxins. Aflatoxin. These are poisonous class of mycotoxins formed by poisonous molds, particularly Aspergillus parasiticus and Aspergillus flavus, which may contaminate food and feed badly. Aflatoxins are liver killers (Goto et al., 1996) and may greatly effect immune system by suppressing system activity (Peterson et al., 2001; Klich et al., 2000). Aflatoxin B1, G1, B2 and G2 are the four main types while aflatoxin M1 is hydroxylated form of B1 which is found in milk and dairy products. B and G stands for blue and green fluorescence character of aflatoxin under UV light, respectively while 1 and 2 refer to position of these aflatoxins on thin layer chromatography. Aflatoxin B2 and G2 are less toxic as compared to B1 and G1 and aflatoxin B2 is less toxic than G1 (Sanchis et al., 1994). The fungi species: (Aspergillus flavus and Aspergillus parasiticus) show suitable growth at warm conditions (Chase and Overton, 2012). Optimum environment for aflatoxin growth is $33^{\circ} \mathrm{C}$ and 0.99 aw (water activity). Aflatoxin growth in food and feed was observed in stressful growing stage, e.g. drought growth conditions. Under harsh situations fungi (molds), spores survive and start decaying vegetation under microbiological actions and under suitable environment attacks on hay and grain especially when moisture content is higher in humid soil (Ominski et al., 1994). Aflatoxins have adverse carcinogenic, toxic, teratogenic and mutagenic effects and also may cause liver and organ cancer in humans. Direct exposure to aflatoxin may occur frequently by ingestion of food and also by other means like dermal contact and inhalation (Mizrak et al., 2009).

Aflatoxins impart their noxious effects on humans and animals health and the severity level of their lethal effects is directly related to nature of aflatoxin, age of consuming body, exposure time and food status of a person. The plants, grains, cereals, spices, nuts and oilseeds that commonly favour the growth of aflatoxin and consequent fungal toxin production are the vital causes of exposure to aflatoxin. The examples are maize, wheat, rice, oilseeds, sunflower, peanut, cotton, almond, pistachio, walnut, coconut and spices like black pepper, red chilli, turmeric and coriander (Van Egmond, 2002). The other commodities which may have aflatoxin contamination are plants parts like vegetables and fruits and also in meat, animal tissues and animal products (Milicevic et al., 2010).

Different countries have adapted different permissible limits of aflatoxins in feed and food entities. The allowable level of aflatoxin in various food entities (Tritscher et al., 2013) in different countries is given in Table 2 .

Table 1. Mycotoxins and their toxic effects

\begin{tabular}{llll}
\hline \hline Mycotoxins & Producing organism & Chemical structure & Effect on mammalian cells \\
\hline $\begin{array}{l}\text { Aflatoxins (B1, G1, } \\
\text { M1, B2, G2, M2) }\end{array}$ & Aspergillus & Difuranocoumarin derivatives & Carcinogenic \\
Ochratoxins & Aspergillus penecillium & $\begin{array}{l}\text { Dihydroisocoumarin derivatives } \\
\text { linked to phenylalanine }\end{array}$ & $\begin{array}{l}\text { Carcinogenic nephrotoxic } \\
\text { hepatotoxic teratogenic }\end{array}$ \\
Citrinin & Penecillium & Benzopyran derivative & Nephrotoxic \\
$\begin{array}{l}\text { Trichothecenes or } \\
\text { Deoxynivalenol }\end{array}$ & $\begin{array}{l}\text { Fusarium } \\
\text { trichoderma }\end{array}$ & Sesquiterpenoid Compounds & Cytotoxic immunosuppressive \\
Fumonisin & Fusarium alternaria & Isoflavanoid compounds & Hepatotoxic carcinogenic \\
Patulin & Aspergillus penecillium & Unsaturated heterocyclic lactones & Carcinogenic immunotoxic \\
& & & $\begin{array}{l}\text { genotoxic } \\
\text { Zearalenone }\end{array}$ \\
& Fusarium & Phenol resorcyclic acid lactone & Esterogenic activity potential \\
& & & carcinogenic and hepatotoxic \\
\hline \hline
\end{tabular}



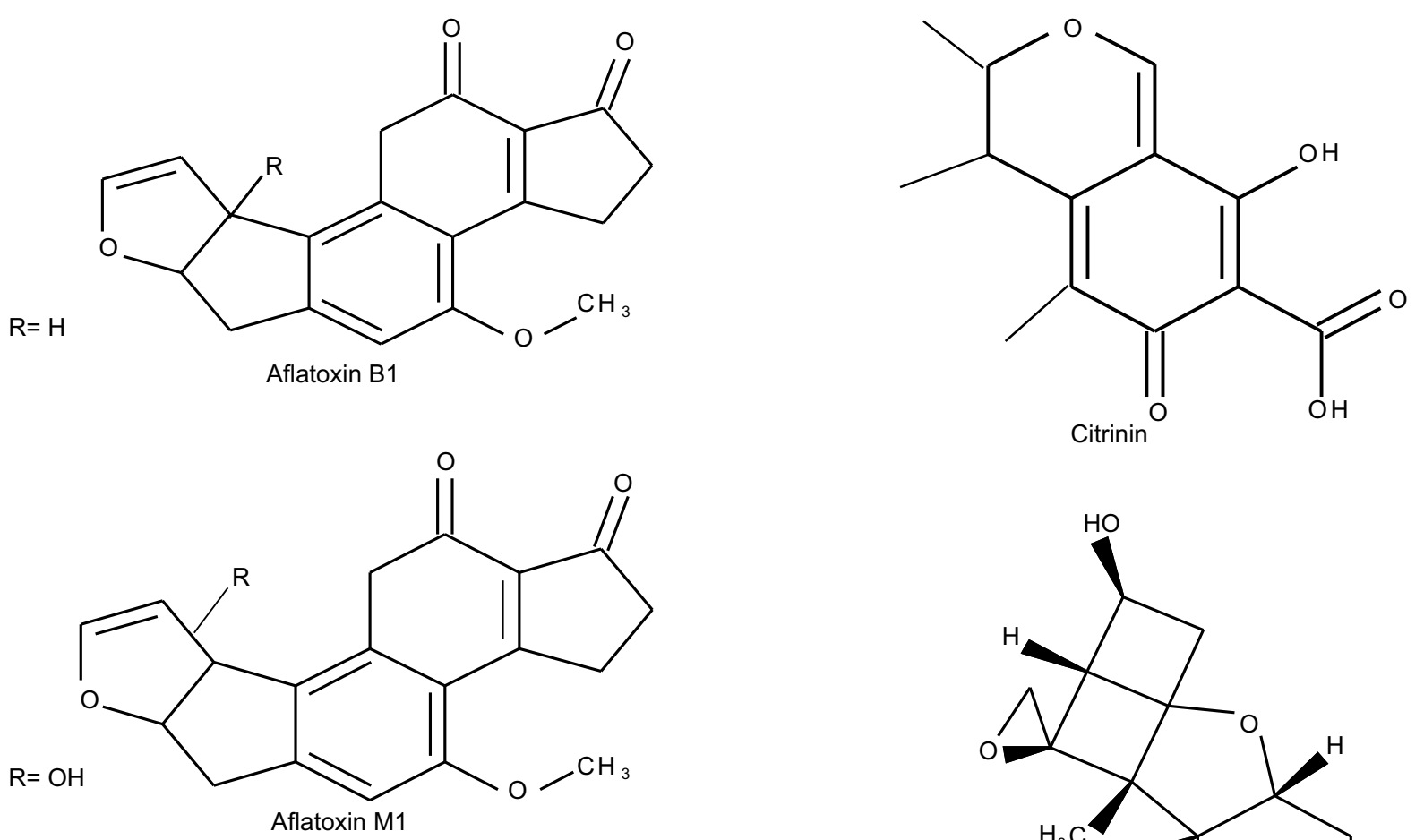<smiles></smiles>

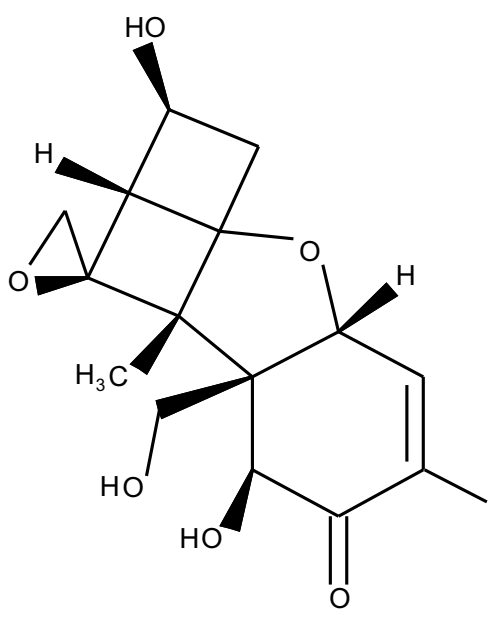

Deoxynivalenol<smiles>CC1CCCC(=O)CCC/C=C/c2cc(O)cc(O)c2C(=O)O1</smiles>
$\mathrm{HO}$<smiles>O=C1C=C2CC(O)OC=C2O1</smiles>

Zearalenone

$$
\text { Patulin }
$$<smiles>CCCCC(C)C(OC(=O)CC(CC(=O)O)C(=O)O)C(CC(C)CC(O)CCCCC(O)CC(O)C(N)CC)OC(=O)CC(CC(=O)O)C(=O)O</smiles>

Fig. 1. Chemical structure of Mycotoxins. 
Table 2. Permissible limits for aflatoxins

\begin{tabular}{llll}
\hline \hline Aflatoxins & $\begin{array}{l}\text { Maximum permissible limit } \\
(\mu \mathrm{g} / \mathrm{kg})\end{array}$ & Product & Country \\
\hline $\begin{array}{l}\text { Total aflatoxins } \\
(\mathrm{B} 1+\mathrm{B} 2+\mathrm{G} 1+\mathrm{G} 2)\end{array}$ & 10 & Groundnuts & China, Egypt, Japan, Thailand, Turkey \\
Total aflatoxins & 15 & Groundnuts & Australia, Indonesia, Malaysia, Taiwan \\
Total aflatoxins & 4 (Direct consumption) & Groundnuts & European Union \\
& 15 (Additional processing) & & \\
Aflatoxin $\mathrm{B}_{1}$ & 2 & & Kenya \\
Total aflatoxins & 20 & Groundnuts & Russia \\
Aflatoxin B $\mathrm{B}_{1}$ & 5 & Groundnuts & Canada \\
Total aflatoxins & 15 & Nuts and subsequent products & Philippines \\
Total aflatoxins & 20 & Nuts and Products & Singapore \\
Total aflatoxins & 5 & Nuts & India \\
Total aflatoxins & 30 & All food products & USA \\
Total aflatoxins & 20 & All foods except milk & Vietnam \\
Total aflatoxins & 10 & Food entities & \\
\hline \hline
\end{tabular}

(Tritscher et al., 2013).

Ochratoxins. The fungal metabolites formed by species Aspergillus ochraceous and Aspergillus penecilliumare are termed as Ochratoxins (Zahra et al., 2016; Bayman et al., 2002). Ochratoxin A is common and pertinent toxin of this group. Ochratoxins A, B and C are structurally related and are equally harmful. Ochratoxin A pollutes agricultural products and due to its growth in food, represents a serious danger equally to human and animal health globally (Jordan and Pattison, 1996). Optimum conditions for ochratoxin growth are at $25-30{ }^{\circ} \mathrm{C}$ and 0.98 aw (water activity). Among three Ochratoxins A is most common and toxic compound found in cereals, barley, nuts, dried fruits, porcine kidney, beer, coffee beans, wines and moldy bread (JECFA, 2001). Ochratoxins are alleged to be involved in the tumors of urinary organs and etiology of human nephropathies (KuiperGoodman et al., 2010). According to the European Commission 2002, ochratoxin infectivity was set at 3 $\mu \mathrm{g} / \mathrm{kg}$ in cereals consequent products. In dry grapes the contamination limit fixes to a limit of $10 \mu \mathrm{g} / \mathrm{kg}$ (El Khoury and Atoui, 2010). This difference in commendations shows differences in risk managing procedures, ensuing different permitted limits functional to diverse food products and to the same goods in various regions (Walker, 2002).

Citrinin. The secondary toxic metabolites of benzopyran created by numerous Aspergillus and Penicillium species particularly by $P$. citrinum are termed as Citrinin mycotoxin. It is usually formed subsequent to harvest and can be found mostly in stock up grains and cereals chiefly rice, barley and wheat and also found in other plant parts like fruits, vegetables and beans. It may also contaminate herbs, juices, spices and dairy products (Abou-Zeid, 2012). Citrinin is nephrotoxic mycotoxin (Ali et al., 2018) which can co-occur in food entities, resulting in internal revelation. Depending on species nature, Citrinin may form at $20-30{ }^{\circ} \mathrm{C}$ and $0.75-0.85$ aw (water activity). Due to this toxin food poisoning reaches its peak especially in countries with a hot and humid weather (Sinha and Prasad, 1996; Frank, 1992). This toxin may affect kidneys and can cause severe renal failure (Degen et al., 2018). Physiological research also identified various unsympathetic effects on gastrointestinal tract and liver as well (Krejci et al., 1996).

Trichothecenes. Trichothecenes are globally dispersed and generally formed by Fusarium species in extreme environments (Nelson et al., 1994). The trichothecenes are categorized in two different groups i.e. nonmacrocyclic or macrocyclic compounds. There are two subdivisions of non-macrocyclic trichothecene compounds i.e., type $\mathrm{A}$ and type $\mathrm{B}$. The type $\mathrm{A}$ includes NEO (neosolaniol), HT-2 toxin, T-2 toxin and DAS (diacetoxyscirpenol). The type B trichothecenes include DON (deoxynivalenol), NIV (nivalenol), 3-AcDON (3-acetyldeoxynivalenol) and 15-AcDON (15-acetyldeoxynivalenol) (Hedayati et al., 2007).

Tricothecenes may cause depression of the immune response, vomiting, blood and reproductive disorders, 
growth retardation, dermatitis and oral lesions (Rocha et al., 2005; CAST, 2003). Optimum conditions (Ramirez et al., 2006) for trichothecenes growth are at $26-30{ }^{\circ} \mathrm{C}$ and 0.995 aw (water activity). The permissible limit of DON in Canadian soft wheat is set at $2 \mathrm{ppm}$ and $1 \mathrm{ppm}$ for infant food. DON allowable limit (Pestka and Smolinski, 2005) in United States, Russia, China, Hungary and Switzerland is set at $1 \mathrm{ppm}$ while in Austria, Germany and Netherlands it is $0.5 \mathrm{ppm}$.

Fumonisins. Fumonisins are the mycotoxins produced by Fusarium verticillioides, F. oxysporum, F. globosum, F. proliferatum and several other Fusarium spp. (Scott, 2012). Its types are Fumonisins B1, Fumonisins B2 and Fumonisins B3. Fumonisins received special attention in 1988 (Marasas et al., 1988) when experiments were conducted in horse and found fumonisins cancer causing activity and the initiation of leukoencephalomalacia.

Fumonisins are mainly found in corn and in corn-based animal feeds. Fumonisin B1 (FB1) is the most frequent and is most meticulously studied. FB1 causes diseases like porcine pulmonary edema (PPE) and equine leukoencephalomalacia (ELEM). FB1 is harmful for the liver in all species and the kidney in some farm animals, causing apoptosis chased by mitosis in the affected tissues (Voss et al., 2007).

Fumonisins may found in different food entities like barley, wheat, millet, oat and maize and concerned products (Aoyama et al., 2010). The optimum growth parameters for Fumonisins are: temperatures $15-30{ }^{\circ} \mathrm{C}$ and 0.9-0995 aw (water activity). The permissible limits of fumonisins in maize products are 2 or $4 \mathrm{mg} / \mathrm{kg}$ for popcorn grain (USFDA, 2001).

Patulin. Patulin is also a toxic type of mycotoxin formed by different fungal species like Penicillium patulum now called Penicillium griseofulvum. Its chemical formula is 4-hydroxy-4H-furo[3,2c]pyran-2(6H)-one. Patulin is harmful for plants and animals, excluding its therapeutic use as an antibiotic (Bennet and Klich, 2003). Patulin is stable in apple and grape juices and also in dry cereals but it may decompose in wet cereals (Moss and Long, 2002; Trucksess and Tang, 2001; Armentia et al., 2000). Optimal growth of patulin was observed at $25{ }^{\circ} \mathrm{C}$. Patulin has been confirmed to be extremely poisonous. It is teratogenic, genotoxic and probably immune-toxic to animals. Uptill now the harmfulness of patulin in humans has not been verified and demonstrated decisively but to limit its concentration in food commodities is taken as a preventive measure (Cunha et al., 2014).

European Guideline 1425/3003 has set a permissible level of patulin i.e. $50 \mu \mathrm{g} / \mathrm{L}$ for fruit juices and derivative products. The permissible limit of patulin is $25 \mu \mathrm{g} / \mathrm{L}$ for apple products while it is $10 \mu \mathrm{g} / \mathrm{L}$ for foods and juices prepared for young infants (Chalmers et al., 2004) while according to USFDA allowable limit for patulin is $50 \mu \mathrm{g} / \mathrm{L}$ (Puel et al., 2010).

Zearalenone. Zearalenone is mainly formed from Fusarium graminearum and F. culmorum fungal species in different cereals including wheat, maize, oats, rye and barley. Zearalenone has been demonstrated to induce infertility, mammary hypertrophy and vulva oedma in various animal females (Zinedine et al., 2007).

Zearalenone may accumulate in different cereals depending upon many factors like temperature, substrate, strain of fungal species and duration of Fusarium growth. It may contaminate both food and feed stuffs (De-Saeger et al., 2003). The favourable temperature and water activity for patulin augmentation was observed at 25 ${ }^{\circ} \mathrm{C}$ and 0.95 aw, respectively.

Zearalenone has categorized as a class $2 \mathrm{~A}$ carcinogen by International Agency for Research on Cancer (IARC, 1993). In 2011, the harmfulness of Zearalenone by the EFSA (European Food Safety Authority) has now been clarified and set a TDI (tolerable daily intake) of 0.25 $\mu \mathrm{g} / \mathrm{kg}$ body weight (EFSA, 2011).

Determination of mycotoxins. Mycotoxin examination gives a picture of harmful fungal infectivity of foods and feeds. There are various chemical and biological ways known since 1970 for detection and quantification. Different organizations like FDA, EPA and AOAC has standardized the process of mycotoxin analysis. Systematic methods have now been developed even to determine low quantity of mycotoxins in food and feed commodities. Proper sampling procedure by fixed legislation (Codex Alimentarius) is essential step in mycotoxin analysis. Mycotoxins are not homogenous in food and feed samples. So, sample extraction and preparation is critical process to achieve good analytical results. Mycotoxins analysis include 3 main steps i.e. extraction, purification and evaluation (Trucksess and Pohland, 2001).

Mycotoxins are purified by different chromatographic and centrifugation methods and also by passing through prepacked cartridges. TLC (thin layer chromatography), 
HPLC (high performance liquid chromatography) with Diode Array detector and Fluorescence detector, GC (gas chromatography) with Mass Spectrometer, LC (liquid chromatography) with Mass Spectrometer and ELISA (enzyme linked immune-sorbent assay) are the popular techniques for the analysis of mycotoxins in diverse food and feed commodities (Onji et al., 2002; Jaimez et al., 2000; Lin et al., 1998).

Mycotoxins control. Mycotoxin contamination may harm humans and animals health so its control is obligatory. Preventive measures should be adapted which include preharvest control, post-harvest control while corrective measures include removing mycotoxins from food and feed stuffs.

Pre-harvest control. Suitable cultivation techniques can reduce mycotoxins. For instance, exclusion of farming waste is helpful in mitigating the contagion of the plants and crops by fungal attack. Fungicides used in field crops may reduce and lower the mycotoxin contamination. Software appliances are accessible to help out farmers predicted mycotoxin threat throughout the year which work according to climatic parameters. Various microorganisms as bio-control agents are proposed to reduce aflatoxin infectivity in pre-harvest; for instance, non-aflatoxigenic strains of the same varieties might be bio-competitive agents (Jard et al., 2011). Resistance propagation is conventionally applied to improve the confrontation of the host plants to fungal attack and infectivity (Anthony et al., 2012). To lowering fumonisin in maize and deoxynivalenol in wheat, biocompetitive exclusion shows capable results (Cleveland et al., 2003). By using genetic engineering the plant genes become less at risk level to fungal infection.

Postharvest control. The contamination of mycotoxin by Aspergillus, Alternaria, Fusarium and Penecillium species is inevitable in different environmental circumstances. Storage and sorting are the main post harvest control parameters. Best storage conditions are necessary to lessen the mycotoxin in food and feed stuffs. Water activity, the presence of chemical preservatives, gas composition, temperature and microbial contacts of the stored products are factors which may affect mycotoxin growth. An integrated control of these factors might give great effective control. No single method used against wide range of mycotoxins which may present with co-contamination. Many strategies are introduced for decontamination of mycotoxins. Infected grains do not have the same colour or density as protected grains. Thus, the contaminated grains must be separated according to density or appearance (Kabak, 2009; Afolabi et al., 2006).

Eliminating mycotoxins from food and feed. The main purpose of detoxification is to inactivate or remove mycotoxins. The nutritional value and deliciousness of foodstuff should be maintained. Several ways and methods have been investigated for lessening mycotoxin infectivity in feed and food stuffs. These methods are categorized as physical, chemical and biological methods (Varga and Tóth, 2005).

Physical methods. The effective control of mycotoxin contamination can be reduced by various physical methods like colour-wise sorting, mechanical separation, removal of the fines and density segregation. Washing of grains by simply water or sodium carbonate solution is used to reduce the concentrations of Zearalenone, Deoxynivalenol and Fumonisins in maize and cereal grains. Gamma radiations were used to control ochratoxin in feeds (Stepanik et al., 2007).

Chemical methods. Aflatoxin contamination is inevitable and capricious which makes it distinctive challenge to both food and feed safety as it directly or indirectly agonies animals and human beings. Although there are many chemicals but it is found that $0.5 \%$ hydrochloric acid is the pre-eminent chemical for decontamination of aflatoxin B1 in fish feed and poultry samples (Nisa et al., 2012a; 2012b). 0.3 and $0.4 \% \mathrm{NaOCl}, 0.5 \% \mathrm{HCl}$, $0.3 \% \mathrm{HCl}, 0.1 \% \mathrm{HCl}, 10 \%$ citric acid, $30 \%$ citric acid, $50 \%$ calcium hydroxide, $96 \%$ ethanol and $99 \%$ acetone were used for detoxification. The aflatoxins were reduced to $55.1 \%$ in super sella rice, $90.9 \%$ in super basmati rice, $28.08 \%$ in brown rice and $80.0 \%$ in white rice samples. Aflatoxins were detoxified in dal chana, dal mash, dal masoor, haldi and kalongi upto 70.5, 83.0, $46.2,82.09$ and $36.9 \%$, respectively. Reduction of aflatoxins was carried out 39.7, 7.1, 39.5, 82.0 and $62.0 \%$ in red chilli, makhana, corn flakes, kheer mix and pistachio. The aflatoxins level was reduced in maize grain, damaged wheat, peanut, figs and dates upto 31.3, 64.3, 63.6, 42.7 and 19.8\%, respectively (Nisa et al., 2013). Ammoniation is an efficient method used for several years and is mainly used to decrease the level of aflatoxins in feed but it may affect food quality. Similarly, alkalization, acidification and thermal treatment may reduce mycotoxin levels in food and feed samples (Bretz et al., 2006). Deamination i.e., addition of $\mathrm{NaNO}_{2}$ reduce aflatoxin $\mathrm{B} 1$ by deaminating and so decrease its toxicity (Lemke et al., 2001). 
Table 3. Overview of studies in some countries regarding different mycotoxins analysis

\begin{tabular}{|c|c|c|c|c|c|c|}
\hline Mycotoxin & $\begin{array}{l}\text { Food } \\
\text { commodity }\end{array}$ & Countries & Sampling year & $\begin{array}{l}\text { No. of } \\
\text { samples }\end{array}$ & $\begin{array}{l}\text { Mycotoxin } \\
\text { contaminated } \\
\text { positive samples } \\
(\%)\end{array}$ & References \\
\hline Aflatoxin B1 & \multirow[t]{2}{*}{ Rice } & \multirow[t]{2}{*}{ Turkey } & \multirow[t]{2}{*}{2009} & \multirow[t]{2}{*}{100} & 35.00 & \multirow[t]{2}{*}{ Buyukunal et al., 2010} \\
\hline Ochratoxins & & & & & 38.00 & \\
\hline Aflatoxin B1 & \multirow[t]{2}{*}{ Animal feed } & \multirow[t]{3}{*}{ Kenya } & \multirow[t]{3}{*}{2015} & 74 & 56.00 & \multirow[t]{3}{*}{ Makau et al., 2016} \\
\hline Deoxynivalenol & & & & 43 & 63.00 & \\
\hline Aflatoxin M1 & Milk & & & 68 & 48.50 & \\
\hline Aflatoxin M1 & Milk & Iran & 2011 & 42 & 1.60 & Ali et al., 2012 \\
\hline Aflatoxins B1, & Peanut & \multirow[t]{6}{*}{ Brazil } & \multirow[t]{6}{*}{ 2011-2012 } & \multirow[t]{6}{*}{240} & 35.00 & \multirow[t]{6}{*}{ Jager et al., 2013} \\
\hline $\mathrm{B} 2, \mathrm{G} 1, \mathrm{G} 2$ & Corn & & & & 42.00 & \\
\hline & Bean & & & & 75.00 & \\
\hline Aflatoxin M1 & Milk & & & & 41.00 & \\
\hline & Cheese & & & & 33.00 & \\
\hline & Yougurt & & & & 0.00 & \\
\hline Aflatoxin M1 & Buffalo Milk & Pakistan & 2013 & 50 & 84.00 & Sajid et al., 2015 \\
\hline & Cow Milk & & & & 72.00 & \\
\hline Zearalenone & Wheat & Egypt & 2013 & 60 & 40.00 & El-Desouky and Naguib, \\
\hline & Corn & & & & 20.00 & \\
\hline & Barley & & & & 26.00 & \\
\hline Trichothecene & Wheat & Czech Republic & $1999-2005$ & 191 & 92.00 & Hajslova et al., 2007 \\
\hline & Barley & & 2005 & 24 & 100.00 & \\
\hline & Rye & & 2001 & 15 & 100.00 & \\
\hline Citrinin & Barley & Egypt & 1994-1995 & 274 & 55.90 & Abd Alla, 1996 \\
\hline & Rice & & & & 39.40 & \\
\hline Patulin & Apple Juices & Turkey & 2001 & 45 & 44.00 & Yurdun et al., 2001 \\
\hline Patulin & Apple products & South Africa & 1996 to 1998 & 60 & 16.00 & Leggott and Shephard, 2001 \\
\hline Aflatoxins & Dried chilli & Thailand & 2004 & 33 & 43.50 & Kladpan et al., 2006 \\
\hline Fumonisin B2 & Coffee bean & Thailand & 2007 & 12 & 58.30 & Noonim et al., 2009 \\
\hline Aflatoxin & Maize products & Brazil & $2002-2003$ & 121 & 1.70 & Sekiyama et al., 2005 \\
\hline Ochratoxin & & & & & 0.80 & \\
\hline Zearalenone & & & & & 0.80 & \\
\hline Zearalenone & Cereals & Timis county, Romania & $2008-2010$ & 125 & 29.60 & Galbenu et al., 2011 \\
\hline Deoxynivalenol & Noodle & Thailand & 2007 & 30 & 6.67 & Poapolathep et al., 2008 \\
\hline & Bread & & & 30 & 16.70 & \\
\hline & Cereals & & & 30 & 33.30 & \\
\hline Deoxynivalenol & Rice & South America & 2009 & 100 & 38.00 & Abbas and Shier, 2009 \\
\hline Zearalenone & & & & & 65.00 & \\
\hline Aflatoxins & Corn & China & 2007 & 283 & 70.30 & Liu, 2007 \\
\hline & Peanuts & & & & 23.10 & \\
\hline Aflatoxin B1 & Cereals and & Yangtze Delta & 2010 & 76 & 14.50 & Li et al., 2014 \\
\hline Ochratoxin & oil products & region of China & & & 14.50 & \\
\hline Deoxynivalenol & & & & & 15.80 & \\
\hline Zearalenone & & & & & 27.60 & \\
\hline Aflatoxin B1 & Maize & India & 2010-2012 & 150 & 18.70 & Mudili et al., 2014 \\
\hline Ochratoxin & & & & & 13.30 & \\
\hline Fumonisin B1 & & & & & 38.70 & \\
\hline Deoxynivalenol & & & & & 15.30 & \\
\hline T-2 Toxin & & & & & 7.33 & \\
\hline Fumonisins & Maize products & Coimbra, Portugal & 2005 & 67 & 22.40 & Silva et al., 2007 \\
\hline Fumonisins & Rice & Canada & 2008 & 99 & 15.20 & $\begin{array}{l}\text { Sarathchandra and } \\
\text { Muralimanohar, } 2013\end{array}$ \\
\hline Aflatoxin B1 & Feed stuff & Tamil Nadu & 2010 & 441 & 52.60 & \\
\hline Ochratoxin & & & & & 23.13 & \\
\hline Citrinin & & & & & 50.11 & \\
\hline T-2 Toxin & & & & & 3.63 & \\
\hline Zearalenone & & & & & 19.50 & \\
\hline Aflatoxin & Brown Rice & Pakistan & $2006-2010$ & 1029 & 22.42 & Nisa et al., 2015 \\
\hline & White Rice & & & 1561 & 33.13 & \\
\hline & Sella Rice & & & 13 & 24.27 & \\
\hline & Parboiled Rice & & & 52 & 26.92 & \\
\hline & Broken Rice & & & 33 & 39.39 & \\
\hline Aflatoxin & Brown Rice & Pakistan & 2015 & 50 & 92.00 & Nisa et al., 2016 \\
\hline Aflatoxin & Chilli & Pakistan & 2012 & 183 & 26.23 & Nisa et al., 2012 \\
\hline Aflatoxin & Brown rice & Pakistan & 2016 & 90 & 56.0 & Zahra et al., 2017 \\
\hline & White rice & & & 60 & 67.0 & \\
\hline Aflatoxin & Pepper & Mexico & 2017 & 54 & 95.0 & Garduño-García et al., 2017 \\
\hline Fumonisins & Garlic & Italy & 2017 & 56 & 5.36 & Tonti et al., 2017 \\
\hline
\end{tabular}


Table 4. Pros and cons of aflatoxin detection tools

\begin{tabular}{|c|c|c|c|}
\hline Technique & Pros & Cons. & References \\
\hline TLC & $\begin{array}{l}\text { - Easy and reliable semi-quantitative way } \\
\text { - Involves no sophisticated equipment }\end{array}$ & $\begin{array}{l}\text { - Obsolete method } \\
\text { - Need HPLC analysis for } \\
\text { quantification results } \\
\text { - Samples destruction during } \\
\text { preparation }\end{array}$ & Rahmani et al., 2009 \\
\hline HPLC & $\begin{array}{l}\text { - Reliable and sensitive quantitative } \\
\text { method }\end{array}$ & $\begin{array}{l}\text { - Very expensive to analyze number } \\
\text { of samples } \\
\text { - Samples destruction during } \\
\text { preparation }\end{array}$ & $\begin{array}{l}\text { Shephard et al., 2012; } \\
\text { Pascale and Visconti, } \\
2008\end{array}$ \\
\hline $\mathrm{GC}$ & $\begin{array}{l}\text { - Good sensitivity } \\
\text { - Simultaneous analysis of mycotoxins } \\
\text { - Provides confirmation (MS detector) }\end{array}$ & $\begin{array}{l}\text { - Amplified trichothecene responses } \\
\text { (up to } 120 \% \text { ), } \\
\text { - Calibration curves non-linearity } \\
\text { - High deviation in terms of } \\
\text { reproducibility and repeatability }\end{array}$ & $\begin{array}{l}\text { Petterson and Langseth, } \\
2002\end{array}$ \\
\hline LC/MS & $\begin{array}{l}\text { - Instantaneous analysis of different } \\
\text { mycotoxins } \\
\text { - Detection limit is low } \\
\text { - No derivatization required }\end{array}$ & $\begin{array}{l}\text { - exceptionally costly equipment } \\
\text { requiring devoted operator to } \\
\text { infer results } \\
\text { - sensitivity depends on ionization } \\
\text { - need internal standards }\end{array}$ & $\begin{array}{l}\text { Li et al., 2013; Krska } \\
\text { et al., } 2008\end{array}$ \\
\hline ELISA & $\begin{array}{l}\text { - Rapid, specific and quite easy to exercise } \\
\text { - concurrent analysis of numerous samples } \\
\text { - semi-quantitative (screening) or } \\
\text { quantitative analysis possible } \\
\text { - partial use of organic solvents } \\
\text { - economical equipment } \\
\text { - low limit of detection }\end{array}$ & $\begin{array}{l}\text { - Probability of false positives/ } \\
\text { negatives } \\
\text { - constricted detection range }\end{array}$ & $\begin{array}{l}\text { Lippolis and Maragos, } \\
2014 \text {; Lattanzio et al., } \\
2011\end{array}$ \\
\hline
\end{tabular}

Biological methods. Bio-transformation by adsorbing, binding or detoxifying can reduce mycotoxins. Hydrated sodium calcium alumino silicates (HSCAS) may reduce aflatoxin B1. HSCAS is very important to prevent aflatoxicosis in a diversity of animals. Activated carbon has ability to adsorb Fumonisins B1 and Ochratoxin A in aqueous solutions. Yeast dried cell mass and wall substance of lactobacillus have ability to merge with mycotoxins. Fungal conidia may bind mycotoxins effectively, especially Zearalenone and Ochratoxins (Jard et al., 2009). Probiotic microorganisms (Saccharomyces cerevisiae and Lactobacillus delbrueckii) were investigated to reduce mycotoxins as biological control agents and found the use of probiotics as an alternative treatment to prevent aflatoxin production in food entities (Silva et al., 2015).

\section{Conclusion}

Mycotoxicoses may cause severe and deadly diseases.
Presence of diverse mycotoxins in food and feed samples may harm to human as well as animal health and also can damage country's economy to great extent. The stringent control of foodstuff quality, in both developing and industrialized regions is very much necessary to avoid cruel and painful circumstances. Sometimes mycotoxin contamination is inevitable and cause huge economic losses. Preventive and corrective measures have great importance regarding the safety of food and feed. There should be strong applicability of rules and regulations in every country to allow the occurrence of permitted limits of these harmful mycotoxins in food and feed stuffs to make food and feed safe. Useful systems like HACCP (Hazard analysis and critical control points) may control the mycotoxins in entire agricultural food chain effectively.

Conflict of Interest. The authors declare no conflict of interest. 


\section{References}

Abbas, H.K., Shier, W.T. 2009. Mycotoxin contamination of agricultural products in the southern United States and approaches to reducing it from preharvest to final food products. ACS Symposium Series, 1031: 37-58.

Abd Alla, E.S.A. 1996. Natural occurrence of Ochratoxin A and citrinin in food stuffs in Egypt. Mycotoxin Research, 12: 41-44.

Abou-Zeid, A.M. 2012. Review on citrinin: production, effect of some plant extracts and gene involved in its biosynthesis. Civil and Environmental Engineering, 2: 113.

Afolabi, C.G., Bandyopadhyay, R., Leslie, J.F., Ekpo, E.J. 2006. Effect of sorting on incidence and occurrence of fumonisins and Fusarium verticillioides on maize from Nigeria. Journal of Food Protection, 69: 2019-2023.

Ali, N., Hossain, K., Degen, G.H. 2018. Blood plasma biomarkers of citrinin and ochratoxin: An exposure in young adults in Bangladesh. Mycotoxin Research, 34: 59.

Ali, M.S., Mohamad, K., Halime, M. 2012. Determination of Aflatoxin M1 in Milk by ELISA Technique in Mashad (Northeast of Iran). ISRN Toxicology, DOI:10.5402/2012121926.

Alrabadi, N.I., Al-Jubury, E.M., Thalij, K.M., Hajeej, J.M. 2018. Lactobacillus rhamnosus ability of aflatoxin detoxification. Jordan Journal of Biological Sciences, 11: 87-92.

Anthony, M.H., Francis, D.M., Patrick, N., Berka, G.T.A., Haruna, O.G. 2012. Aflatoxin contamination in foods and feeds: A special focus on Africa. https:// www.intechopen.com/books. Trends in Vital Food and Control Engineering, DOI:10.5772/24919.

Aoyama, K., Nakajima, M., Tabata, S., Ishikuro, E., Tanaka, T., Norizuki, H., Itoh, Y., Fujita, K., Kai, S., Tsutsumi, T., Takahashi, M. 2010. Four-year surveillance for ochratoxin A and fumonisins in retail foods in Japan. Journal of Food Protection, 73: 344-352.

Armentia, A., Jalon, M., Urieta, I., Macho, M.L. 2000. Monitoring for presence of patulin in apple juices and ciders sold in the Basque Country. Alimentaria, 310: $65-70$.

Bayman, P., Baker, J.L., Doster, M.A., Michailides, T.J., Mahoney, N.E. 2002. Ochratoxin production by the Aspergillus ochraceus group and Aspergillus alliaceus. Applied and Environmental Microbiology, 68: 2326-2329.
Benkerroum, N. 2016. Mycotoxins in dairy products: A review. International Dairy Journal, 62: 63-75.

Bennet, J.W., Klich, M. 2003. Mycotoxins. Clinical Microbiology Reviews, 16: 497-516.

Bennett, J.W. 1987. Mycotoxins, mycotoxicoses, mycotoxicology and Mycopathologia. Mycopathologia, 100: $3-5$.

Berthiller, F., Cramer, B., Iha, M.H., Krska, R., Lattanzio, V.M.T., MacDonald, S., Malone, R.J., Maragos, C., Solfrizzo, M., Stranska-Zachariasova, M., Stroka, J. 2018. Developments in mycotoxin analysis: an update for 2016-2017. World Mycotoxin Journal, 11: 5.

Bretz, M., Beyer, M., Cramer, B., Knecht, A., Humpf, H.U. 2006. Thermal degradation of the Fusarium mycotoxin deoxynivalenol. Journal of Agricultural and Food Chemistry, 54: 6445-6451.

Buyukunal, S.K., Kahraman, T., Ciftcioglu, G.R. 2010. Occurrence of AF, AFB1, OTA in rice commercialized in eastern Turkey. Polish Journal of Environmental Studies, 19: 907-912.

CAST, 2003. Mycotoxins: Risks in Plant, Animal and Human Systems, Task Force Report No. 139, Council for Agricultural Science and Technology, Ames, IA, USA.

Chalmers, I., Clarke, M. 2004. Commentary: The 1944 patulin trial: the first properly controlled multicentre trial conducted under the aegis of the British Medical Research Council. International Journal of Epidemiology, 33: 253-260.

Chase, L., Overton, T. 2012. Identifying and dealing with molds and mycotoxins in feeds. Eastern Dairy Business, 19.

Cleveland, T.E., Dowd, P.F., Desjardins, A.E., Bhatnagar, D., Cotty, P.J. 2003. United States Department of Agriculture-Agricultural Research Service research on pre-harvest prevention of mycotoxins and mycotoxigenic fungi in US crops. Pest Management Science, 59: 629-642.

Creppy, E.E. 2002. Update of survey, regulation and toxic effects of mycotoxins in Europe. Toxicology Letters, 127: 19-28.

Cunha, S.C., Faria, M.A., Pereira, V.L., Oliveira, T.M., Lima, A.C., Pinto, E. 2014. Patulin assessment and fungi identification in organic and conventional fruits and derived products. Food Control, 44: 185190.

Degen, G.H., Ali, N., Gundert-Remy, U. 2018. Preliminary data on citrinin kinetics in humans and their 
use to estimate citrinin exposure based on biomarkers. Toxicology Letters, 282: 43-48.

DeSaeger, S., Sibanda, L., VanPeteghem, C. 2003. Analysis of zearalenone and a-zearalenol in animal feed using high-performance liquid chromatography. Analytica Chimica Acta, 487: 137-143.

EFSA, 2011. Scientific opinion on the risks for animal and public health related to the presence of Alternaria toxins in feed and food. Panel on Contaminants in the food chain (CONTAM). European Food Safety Authority, EFSA Journal, 9: 2407.

El-Desouky, T., Naguib, K. 2013. Occurrence of zearalenone contamination in some cereals. Egyptian Journal of Agro Processes and Technology, 19: 445-450.

El-Khoury, A., Atoui, A. 2010. Ochratoxin A: general overview and actual molecular status. Toxins, 2: 461-493.

FAO, 1997. Worldwide Regulations for Mycotoxins, 1995. A Compendium. FAO Food and Nutrition Paper No. 64, Rome, Italy.

Frank, H.K. 1992. Citrinin. Zeitschrift für Ernährungswissenschaft, 31: 164-177.

Galbenu, P., Damiescu, L., Trif, A., Galbenu, P., Damiescu, L., Trif, A. 2011. Zearalenone occurrence in cereal and cereal-based foodstuffs marketed in Timis County. Research Journal of Agriculture Sciences, 43: 43-49.

Garduño-García, J.I., Carvajal-Moreno, M., RojoCallejas, F., Ruiz-Velasco, S. 2017. Detection of aflatoxins, mutagens and carcinogens in black, white and green peppers (Piper nigrum L.). Journal of Microbial and Biochemical Technology, 9: 095104.

Gizachew, D., Szonyi, B., Tegegne, A., Hanson, J., Grace, D. 2016. Aflatoxin contamination of milk and dairy feeds in the Greater Addis Ababa milk shed, Ethiopia. Food Control, 59: 773-779.

Goto, T., Wicklow, D.T., Ito, Y. 1996. Aflatoxin and cyclopiazonic acid production by a sclerotiumproducing Aspergillus tamarii strain. Applied and Environmental Microbiology, 62: 4036-4038.

Hajslova, J., Lancova, K., Sehnalova, M., Krplova, A., Zachariasova, M., Moravcova, H., Nedelnik, J., Markova, J., Ehrenbergerova, J. 2007. Occurrence of trichothecene mycotoxins in cereals harvested in the Czech Republic. Czech Journal of Food Sciences, 25: 339-350.

Hedayati, M.T., Pasqualotto, A.C., Warn, P.A., Bowyer, P., Denning, D.W. 2007. Aspergillus flavus: human pathogen, allergen and mycotoxin producer. Microbiology, 153: 1677-1692.

IARC, 1993. Some Naturally Occurring Substances: Food Items and Constituents, Heterocyclic Amines and Mycotoxins, International Agency for Research on Cancer. Monographs on the Evaluation of Carcinogenic Risks to Humans, 56: 397.

Jager, A.V., Tedesco, M.P., Souto, P.C.M.C., Oliveira, C.A.F. 2013. Assessment of aflatoxin intake in São Paulo, Brazil. Food Control, 33: 87-92.

Jaimez, J., Fente, C.A., Vazquez, B.I., Franco, C.M., Cepeda, A., Mahuzier, G., Prognon, P. 2000. Application of the assay of aflatoxins by liquid chromatography with fluorescence detection in food analysis. Journal of Chromatography A, 882: 1-10.

James, B. 2005. Public Awareness of Aflatoxin and Food Quality Control in Benin. International Institute of Tropical Agriculture Annual Report, Nigeria.

Jard, G., Liboz, T., Mathieu, F., Guyonvarc'H, A., Lebrihi, A. 2011. Review of mycotoxin reduction in food and feed: from prevention in the field to detoxification by adsorption or transformation. Food Additives and Contaminants: Part A, 28: 1590-1609.

Jard, G., Liboz, T., Mathieu, F., Guyonvarc'H, A., Lebrihi, A. 2009. Adsorption of zearalenone by Aspergillus japonicus conidia: new trends for biological decontamination in animal feed. World Mycotoxin Journal, 2: 391-397.

JECFA, 2001. Safety Evaluation of Certain Mycotoxins in Food. Joint FAO/WHO Expert Committee on Food Additives. Meeting, World Health Organization, \& International Program on Chemical Safety. WHO Food Additives Series 47, FAO and Nutrition Paper 74.

Jordan, F.T., Pattison, M. 1996. Poultry Diseases, 546 pp., $4^{\text {th }}$ edition, WB Saunders Company Ltd., USA.

Kabak, B. 2009. The fate of mycotoxins during thermal food processing. Journal of the Science of Food and Agriculture, 89: 549-554.

Kladpan, S., Mahakarnchanakul, W., Yongmanitchai, V., Boonyaratanakornkit, M., Chinabuti, A. 2006. The survey of aflatoxins contamination and management approach to reduce aflatoxins in peanuts and products and dried chilli in Thailand in 2004. JSM Mycotoxins, 2006: 219-224.

Klich, M.A., Mullaney, E.J., Daly, C.B., Cary, J.W. 2000. Molecular and physiological aspects of 
aflatoxin and sterigmatocystin biosynthesis by Aspergillus tamarii and A. ochraceous. Applied Microbiology and Biotechnology, 53: 605-609.

Krejci, M.E., Bretz, N.S., Koechel, D.A. 1996. Citrinin produces acute adverse changes in renal function and ultra structure in pentobarbital anesthetized dogs without concomitant reductions in (Potassium) plasma. Toxicology, 106: 167-177.

Krska, R., Schubert-Ullrich, P., Molinelli, A., Sulyok, M., MacDonald, S., Crews, C. 2008. Mycotoxin analysis: an update. Food Additives and Contaminants, 25: 152-163.

Kuiper-Goodman, T., Hilts, C., Billiard, S.M., Kiparissis, Y., Richard, I.D.K., Hayward, S. 2010. Health risk assessment of ochratoxin A for all age-sex strata in a market economy. Food Additives and Contaminants, 27: 212-240.

Lattanzio, V.M.T., Gatta, S.D., Godula, M., Visconti, A. 2011. Quantitative analysis of mycotoxins in cereal foods by collision cell fragmentation-highresolution mass spectrometry: performance and comparison with triple-stage quadrupole detection. Food Additives and Contaminants A, 28: 14241437.

Leggott, N.L., Shephard, G.S. 2001. Patulin in South African commercial apple products. Food Control, 12: 73-76.

Lemke, S.L., Ottinger, S.E., Ake, C.L., Mayura, K., Phillips, T.D. 2001. Deamination of fumonisin $\mathrm{B}_{1}$ and biological assessment of reaction product toxicity. Chemical Research in Toxicology, 14: 1115.

Li, P., Zhang, Z., Hu, X., Zhang, Q. 2013. Advanced hyphenated chromatographic-mass spectrometry in mycotoxin determination: Current status and prospects. Mass Spectrometry Reviews, 32: 420452.

Li, R., Wang, X., Zhou, T., Yang, D., Wang, Q., Zhou, Y. 2014. Occurrence of four mycotoxins in cereal and oil products in Yangtze Delta region of China and their food safety risks. Food Control, 35: 117122.

Lin, L., Zhang, J., Wang, P., Wang, Y., Chen, J. 1998. Thin-layer chromatography of mycotoxins and comparison with other chromatographic methods. Journal of Chromatography A, 815: 3-20.

Lippolis, V., Maragos, C. 2014. Fluorescence polarisation immunoassays for rapid, accurate and sensitive determination of mycotoxins. World Mycotoxin Journal, 7: 479-490.
Liu, J. 2007. Contamination of aflatoxins in different kinds of foods in China. Biomedical and Environmental Sciences, 20: 483-487.

Makau, C.M., Matofari, J.W., Muliro, P.S., Bebe, B.O. 2016. Aflatoxin $B_{1}$ and Deoxynivalenol contamination of dairy feeds and presence of Aflatoxin $\mathrm{M}_{1}$ contamination in milk from smallholder dairy systems in Nakuru, Kenya. International Journal of Food Contamination, 3: 1-10.

Marasas, W.F.O., Kellerman, T.S., Gelderblom, W.C. A., Coetzer, J.A., Thiel, P.G., Van Der Lugt, J.J. 1988. Leukoencephalomalacia in a horse induced by fumonisin $\mathrm{B}_{1}$ isolated from Fusarium moniliforme. Onderstepoort Journal of Veterinary Research, 55: 197-203.

Marin, S., Ramos, A.J., Cano-Sancho, G., Sanchis, V. 2013. Mycotoxins: Occurrence, toxicology, and exposure assessment. Food and Chemical Toxicology, 60: $218-237$.

Milani, J.M. 2013. Ecological conditions affecting mycotoxin production in cereals: a review. Veterinarni Medicina, 58: 405-411.

Milicevic, D.R., Škrinjar, M., Baltic, T. 2010. Real and perceived risks for mycotoxin contamination in foods and feeds: challenges for food safety control. Toxins, 2: 572-592.

Mizrak, D., Engin, B., Onder, F.O., Yener, B., Bektas, M., Biyikli, Z., Idilman, R., Cinar, K., Karayalcin, K., Ersöz, S., Karayalçin, S. 2009. Aflatoxin exposure in viral hepatitis patients in Turkey. The Official Journal of Turkish Society of Gastroenterology, 20: 192-197.

Moss, M.O., Long, M.T. 2002. Fate of patulin in the presence of the yeast Saccharomyces cerevisiae. Food Additives and Contaminants, 19: 387-399.

Mudili, V., Siddaih, C.N., Nagesh, M., Garapati, P., Naveen Kumar, K., Murali, H.S., Yli Mattila, T., Batra, H.V. 2014. Mould incidence and mycotoxin contamination in freshly harvested maize kernels originated from India. Journal of the Science of Food and Agriculture, 94: 2674-2683.

Nelson, P.E., Dignani, M.C., Anaissie, E.J. 1994. Taxonomy, biology, and clinical aspects of Fusarium species. Clinical Microbiology Reviews, 7: 479504.

Nisa, A., Zahra, N., Yasha, N.B. 2016. Comparative study of aflatoxins in brown rice samples of local and import quality. International Food Research Journal, 23: 243-247.

Nisa, A., Zahra, N., Hina, S. 2015. Detection of 
Aflatoxins in rice samples. Bangladesh Journal of Scientific and Industrial Research, 49: 189-194.

Nisa, A., Zahra, N., Hina, S., Hayat, R., Ejaz, N. 2013. Quantification and detoxification of aflatoxins in food items. Pakistan Journal of Scientific and Industrial Research, 56: 98-104.

Nisa, A., Zahra, N., Firdous, S., Ejaz, N., Hina, S. 2012a. Detection of aflatoxins in various samples of red chilli. Pakistan Journal of Scientific and Industrial Research, 55: 27-29.

Nisa, A., Zahra, N., Hina, S., Ejaz, N. 2012b. Detoxification of aflatoxin $\mathrm{B}_{1}$ in poultry and fish feed by various chemicals. Pakistan Journal of Scientific and Industrial Research, 55: 154-158.

Noonim, P., Mahakarnchanakul, W., Nielsen, K.F., Frisvad, J.C., Samson, R.A. 2009. Fumonisin $B_{2}$ production by Aspergillus niger in Thai coffee beans. Food Additives and Contaminants, 26: 94100.

Ominski, K.H., Marquardt, R.R., Sinha, R.N., Abramson, D. 1994. Ecological aspects of growth and mycotoxin production by storage fungi. In: Mycotoxins in Grains: Compounds other than Aflatoxins. J. D. Miler and H. L. Trenholm (eds.), 287 pp., Eagan Press, St. Paul, Minnesota, USA.

Onji, Y., Okayama, A., Yasumura, K., Tamaki, M. 2002. Two-dimensional liquid chromatographic separation of aflatoxins $\mathrm{B}_{1}, \mathrm{~B}_{2}, \mathrm{G}_{1}$ and $\mathrm{G}_{2}$ in spices. Mycotoxins, 52: $115-121$.

Pascale, M., Visconti, A. 2008. Overview of detection methods for mycotoxins. In: Mycotoxins Detection Methods, Management, Public Health and Agricultural Trade. pp. 171-183, CAB International, UK.

Peraica, M., Radic, B., Lucic, A., Pavlovic, M. 1999. Toxic effects of mycotoxins in humans. Bulletin of World Health Organization, 77: 754-766.

Pestka, J.J., Smolinski, A.T. 2005. Deoxynivalenol: toxicology and potential effects on humans. Journal of Toxicology and Environmental Health, 8: 3969.

Petterson, H., Langseth, W. 2002. Intercomparison of trichothecenes analysis and feasibility to produce certified calibrants and reference material. European Commission BCR Information Project Reports: EUR 20285/1 EN and EUR 20285/2 EN.

Peterson, S.W., Ito, Y., Horn, B.W., Goto, T. 2001. Aspergillus bombycis, a new aflatoxigenic species and genetic variation in its sibling species, A. nomius. Mycologia, 93: 689-703.

Poapolathep, A., Poapolathep, S., Klangkaew, N., Sugita-
Konishi, Y., Kumagai, S. 2008. Detection of deoxynivalenol contamination in wheat products in Thailand. Journal of Food Protection, 71: 19311933.

Puel, O., Galtier, P., Oswald, I.P. 2010. Biosynthesis and toxicological effects of patulin. Toxins, 2: 613631.

Rahmani, A., Jinap, S., Soleimany, F. 2009. Qualitative and quantitative analysis of mycotoxins. Comprehensive Reviews in Food Science and Food Safety, 8: $202-251$.

Ramirez, M.L., Chulze, S., Magan, N. 2006. Temperature and water activity effects on growth and temporal deoxynivalenol production by two Argentinean strains of Fusarium graminearum on irradiated wheat grain. International Journal of Food and Microbiology, 106: 291-296.

Rocha, O., Ansari, K., Doohan, F.M. 2005. Effects of trichothecene mycotoxins on eukaryotic cells: a review. Food Additives and Contaminants, 22: 369-378.

Sajid, M.W., Randhawa, M.A., Zahoor, T., Sultan, J.I. 2015. Quantitative assessment of Aflatoxin (AFM1) in milk collected from dairy farms in Faisalabad, Pakistan. Journal of the Chemical Society of Pakistan, 37: 594-598.

Sanchis, V., Abadias, M., Oncins, L., Sala, N., Vinas, I., Canela, R. 1994. Occurrence of fumonisins $B_{1}$ and $\mathrm{B}_{2}$ in corn-based products from the Spanish market. Applied and Environmental Microbiology, 60: 2147-2148.

Sarathchandra, G., Muralimanohar, B. 2013. Occurrence of mycotoxins in livestock feeds and feed stuffs of Tamil Nadu. Journal of Environmental Biology, 34: 825-830.

Scott, P.M. 2012. Recent research on fumonisins: a review. Food Additives and Contaminants, 29: 242-248.

Sekiyama, B.L., Ribeiro, A.B., Machinski, P.A., Machinski, J.M. 2005. Aflatoxins, ochratoxin A and zearalenone in maize-based food products. Brazilian Journal of Microbiology, 36: 289-294.

Shephard, G.S., Berthiller, F., Burdaspal, P.A., Crews, C., Jonker, M.A., Krska, R., Lattanzio, V.M.T., MacDonald, S., Malone, R.J., Maragos, C., Sabino, M. 2012. Developments in mycotoxin analysis: an update for 2011-2012. World Mycotoxin Journal, 6: 3-30.

Silva, J.F.M.D., Peluzio, J.M., Prado, G., Madeira, J.E.G.C., Silva, M.O., deMorais, P.B., Rosa, C.A., 
Pimenta, R.S., Nicoli, J.R. 2015. Use of probiotics to control aflatoxin production in peanut grains. The Scientific World Journal, 2015: 959138.

Silva, L.J.G., Lino, C.M., Pena, A., Moltó, J.C. 2007. Occurrence of fumonisins B1 and B2 in Portuguese maize and maize-based foods intended for human consumption. Food Additives and Contaminants, 24: 381-390.

Sinha, K.K., Prasad, G. 1996. Effects of citrinin on pigment, protein and nucleic acid contents in maize seeds. Biologia Plantarum, 38: 317-320.

Stepanik, T., Kost, D., Nowicki, T., Gaba, D. 2007. Effects of electron beam irradiation on deoxynivalenol levels in distillers dried grain and solubles and in production intermediates. Food Additives and Contaminants, 24: 1001-1006.

Steyn, P.S. 1995. Mycotoxins, general view, chemistry and structure. Toxicology Letters, 82: 843-851.

Tola, M., Kebede, B. 2016. Occurrence, importance and control of mycotoxins: A review. Cogent Food and Agriculture, 2: 1191103.

Tonti, S., Mandrioli, M., Nipoti, P., Pisi, A., Toschi, T. G., Prodi, A. 2017. Detection of Fumonisins in fresh and dehydrated commercial garlic. Journal of Agricultural and Food Chemistry, 65: 7000-7005.

Tritscher, A., Miyagishima, K., Nishida, C., Branca, F. 2013. Ensuring food safety and nutrition security to protect consumer health: 50 years of the Codex Alimentarius Commission. Bulletin of the World Health Organization, 91: 468-468.

Trucksess, M.W., Pohland, A.E. (eds.). 2001. Mycotoxin Protocols. Methods in Molecular Biology. vol. 157, Springer, Germany.

Trucksess, M.W., Tang, Y. 2001. Solid phase extraction method for patulin in apple juice and unfiltered apple juice. Methods in Molecular Biology, 157: 205-213.

USFDA, 2001. Food and Drug Administration. Guidance for Industry: Fumonisin levels in human foods and animal feeds; Final guidance. Washington (DC): US Food and Drug Administration (cited 2010 Sept 15).

Van Egmond, H.P. 2002. Worldwide Regulations for Mycotoxins. In: Mycotoxins and Food Safety.
257 pp., Springer, USA.

Varga, J., Tóth, B. 2005. Novel strategies to control mycotoxins in feeds: A review. Acta Veterinaria Hungarica, 53: 189-203.

Voss, K.A., Smith, G.W., Haschek, W.M. 2007. Fumonisins: toxicokinetics, mechanism of action and toxicity. Animal Feed Science and Technology, 137: 299.

Walker, R. 2002. Risk assessment of ochratoxin: current views of the European Scientific Committee on Food, the JECFA and the Codex Committee on Food Additives and Contaminants. In: Mycotoxins and Food Safety. 249 pp., Springer, USA.

WHO, 2006. Mycotoxins in African foods: Implications to food safety and health, World Health Organization. AFRO Food Safety (FOS), Issue No. July 2006.

Yu, J., Chang, P.K., Ehrlich, K.C., Cary, J.W., Bhatnagar, D., Cleveland, T.E., Payne, G.A., Linz, J.E., Woloshuk, C.P., Bennett, J.W. 2004. Clustered pathway genes in aflatoxin biosynthesis. Applied and Environmental Microbiology, 70: 1253-1262.

Yurdun, T., Omurtag, G.Z., Ersoy, Ö. 2001. Incidence of patulin in apple juices marketed in Turkey. Journal of Food Protection, 64: 1851-1853.

Zahra, N., Jamil, N., Ahmad, S.R., Kalim, I., Saeed, K.S.M., James, N., Marriam, M. 2016. Ochratoxin: A potent carcinogen, A review. International Research Journal of Biological Sciences, 5: 2126.

Zahra, N., Jamil, N., Ahmad, S.R., Munir, S., Saeed, M.K., Kalim, I. 2017. Comparative analysis of brown and white rice samples for the presence of Aflatoxin $\mathrm{B}_{1}$ contamination and effect of environment temperature on Aflatoxin concentration during storage. Transylvanian Review, 25: 4507-4515.

Zain, M.E. 2011. Impact of mycotoxins on humans and animals. Journal of Saudi Chemical Society, 15: 129.

Zinedine, A., Soriano, J.M., Molto, J.C., Manes, J. 2007. Review on the toxicity, occurrence, metabolism, detoxification, regulations and intake of zearalenone: an oestrogenic mycotoxin. Food and Chemical Toxicology, 45: 1-18. 